Konstantin Kupchenko (Константин Купченко)

Smoleńska Filia Rosyjskiego Uniwersytetu Ekonomicznego

im. Plechanowa

Smoleński oddział Rosyjskiej Akademii Gospodarki Narodowej i Służby Cywilnej przy Prezydencie Federacji Rosyjskiej (Rosja)
OBLICZA WOJNY

TOM 5 MIASTO I WOJNA

ŁÓDŹ 2021 •ISBN 978-83-8220-699-9 • s. 89-106

https://doi.org/10.18778/8220-699-9.06

ORCID ID: 0000-0001-8674-9650

Natalya Nikitina (Наталья Никитина)

Smoleński Uniwersytet Państwowy (Rosja)

iD ORCID ID: 0000-0002-2545-9112

\title{
УПРАВЛЕНИЕ СМОЛЕНСКОМ В ПЕРИОД ОСАДЫ 1609-1611 ГГ.
}

Streszczenie. Artykuł porusza mało zbadaną problematykę funkcjonowania organów administracyjnych Smoleńska w czasie jego obrony w latach 1609-1611. Opierając się na materiałach źródłowych oraz współczesnej historiografii, zbadano zagadnienie gospodarczego funkcjonowania Smoleńska we wskazanym okresie. Do tej pory nie przeprowadzono wystarczających studiów dotyczących problematyki codziennego zarządzania tym miastem, informacji na ten temat nie znajdzie się ani w szczegółowych, ani w całościowych opracowaniach historii regionu w czasie Wielkiej Smuty. Artykuł opiera się na ścisłym przestrzeganiu zasady historyzmu. Wykorzystano w nim najnowsze naukowe wytyczne metodologiczne dotyczące współczesnych kierunków badań historycznych. Zintegrowane podejście zastosowane w pracy badawczej wynika z następujących metod: opisu historycznego, analizy historycznej, porównawczej oraz mikrohistorii. Podczas pracy z materiałem archiwalnym zastosowano cały kompleks heurystyk archiwalnych. Autorzy zastanawiają się, czy w tym czasie nastąpiły jakieś zmiany w strukturze władz miejskich i jakie struktury w okresie obrony miasta sprawowały władzę nad ludnością Smoleńska. Rozważają uprawnienia, kompetencje i rzeczywiste działania organów administracji wojewódzkiej oraz administracji cywilnej. Dochodzą do wniosku, że cała władza w mieście była w rękach gubernatora. To od niego pochodziły wszystkie rozkazy dotyczące organizacji armii smoleńskiej, wzmocnienia zdolności obronnych i regulacji życia mieszkańców w czasie oblężenia. Jednocześnie zauważono, że w jego trakcie w latach 1609-1611 w Smoleńsku powstała swoista korporacja wojskowych i cywilnych władz administracyjnych, koordynująca wspólne działania w zakresie obrony miasta.

Słowa kluczowe: Smoleńsk, Wielka Smuta, izba wojewódzka, izba ziemstwa, obrona, mieszczanie, milicja 
На протяжении столетий Смоленская земля являмась уникальным регионом с богатой политической историей, своеобразным перекрестком западноевропейской и восточноевропейской цивилизаций, местом синтеза и одновременно конфликта различных культур. В раннее Новое время (XVI-XVIII вв.) история Смоленска тесно связана как с историей Речи Посполитой, так и с политической историей всей Европы. Особенно значимым в этом отношении бым XVII в., когАа сам город пережил три осады, а Смоленская земля, являясь объектом споров межАу Польско- Аитовским и Московским государствами, переходила из рук в руки и почти непрерывно явцялась местом военных ристалищ.

Смоленском интересовацись на всем континенте, но именно ближайшие соседи старались заполучить его в свои руки. О значении, которое Польша придаваца этой территории, свидетельствует высокое место Смоленского воеводства в сейме Речи Посполитой. Его представители занимали в иерархии административных единиц место, равное Мазовецкому воеводству с Варшавой и Минскому воеводству.

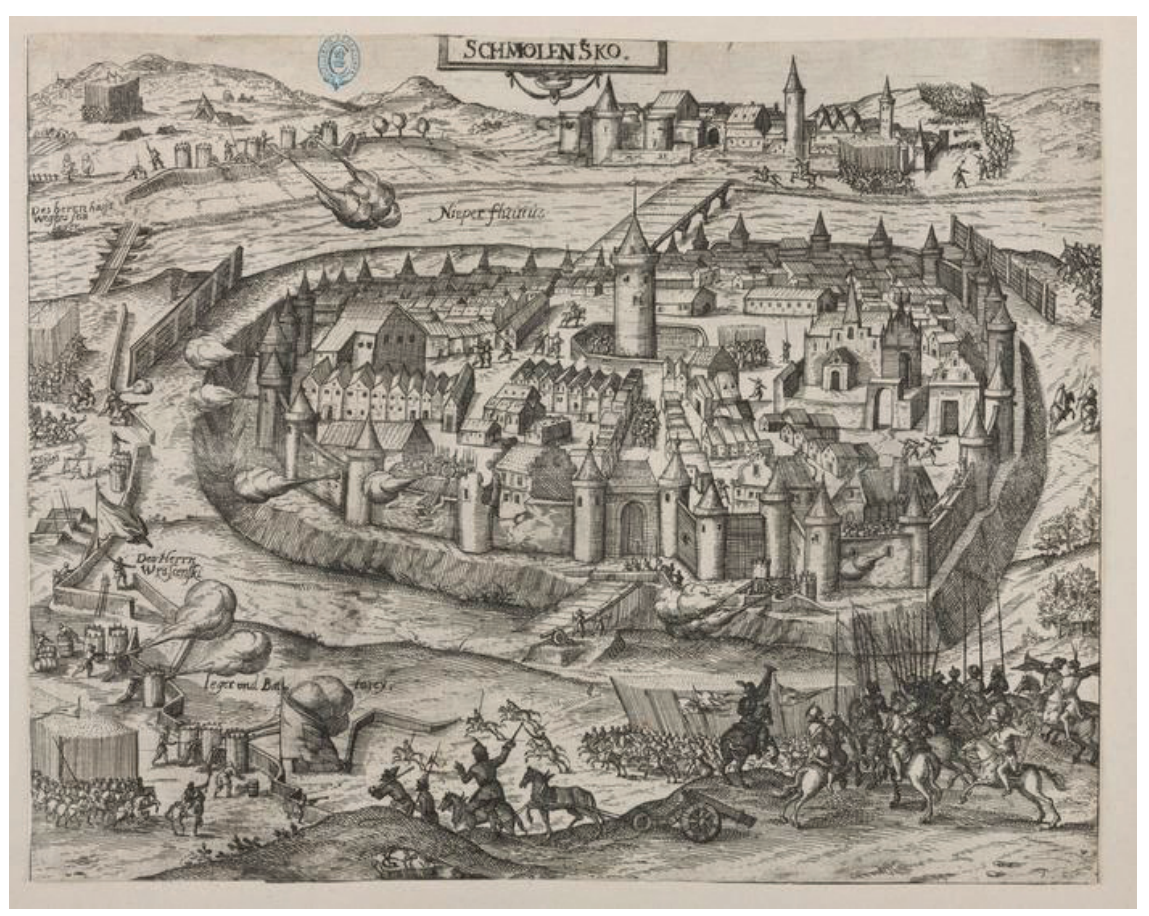

Рис. 1. Осада Смоленска 1609-1611 (Гравюра XVII в., автор неизвестен) 
В 2021 г. исполняется 410 мет окончания осады Смоленска в эпоху

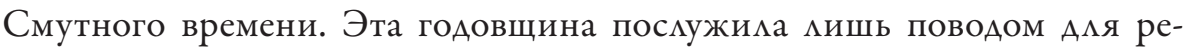
шения давно назревшей и важной проблемы, которая специально не исследовалась ни в отечественной, ни в зарубежной историографии. В частности, речь идет о комплексном изучении деятельности гражданской и военной администрации Смоленска в период осады 1609-1611 гг. На преодоление макунарности данной проблемы и направлено данное исследование.

История обороны Смоленска в 1609-1611 гг. неоднократно становицась предметом специацьных исследований, среди которых наиболее значимыми явцяются работы Н. РаАкова, В.П. Мальцева, С.В. Александрова, И.О. Тюменцева и ряда других ученых ${ }^{1}$. Молочниковым А.М. проведены масштабные исследования относительно Смоленких военно-административных корпораций Смутного времени в России начаца XVII столетия ${ }^{2}$. Исследователами привлечены отдельные сохранившиеся документы Московских приказов, Смоленской приказной избы, Аанные метописей, хронографов и записок иностранцев, присутствовавших во время описываемых событий в русском государстве.

${ }^{1}$ Н. РАаков, Смоленск в Смутное время, [в:] Смоленская старина, ч. 2, Смоленск 1914; Смоленская оборона, Смоленск 1939; В.П. МАльцев, Борьба за Смоленск, Смоленск 1940; С. ААЕКСАНАРОв, Смоленскал осада 1609-1611 г2., Смоленск 2011; А.А. СЕлИН, Королевские пожалования под Смоленском: случай Ржевских, „Аревняя Русь. Вопросы медиевистики” 2017, № 3 (69), s. 122-123; А.А. СЕлин, Женшины в осаждённом Смоленске, [в:] Аа веселится Новъградъ. Ма Novgorod fröjda sig Hyllningsskrift till Elisabeth Löfstrand, Utg. P. Ambrosiani, P. Bodin, N. ZoRikHina Nilsson, Stockholm 2016, c. 207-220; И.О. Тюменцев, Н.А. ТуПикова, Н.Е. ТюменЦевА, С.В. МИРСКИй, Польский коронньй гетман Станислав Жолкевский и Ян Сапега летом-осенью 1610 2. (по материалам личной переписки), „Вестник Волгоградского государственного университета", серия 4: История. Регионоведение. Международнье отношени, 2005, вып. 10, с. $108-125$ и Ар.

2 А.М. Молочников, Смоленский служильй город в Смутное время: Аиссертация ...канАиАата исторических наук: 07.00.02 (Молочников Александр Михайлович), место защиты: Санкт-Петербургский институт истории РАН, Санкт-Петербург 2014, с. 237; IDEM, Смоленские стрелещкие приказы и их руководители в Смутное время [Электронный ресурс], „История военного дела: исследования и источники" 2012, № 3, с. 321-369; IDEM, Стрелецкие сотни в Смоленской обороне 1609-1611 гг. К проблеме статистического анализа, [в:] Четвертая Международная научно-практическая конферениия «Война и оружие. Новые исследования и материальљ». 15-17 мая 2013 г., Санкт-Петербург 2013, с. 262-272; IDEм, Смоленский служильй город Смутного времени, часть 1: Поместное верстание 7114 (1605/06) года [Электронный ресурс], „История военного дема: исследования и источники” 2013, № 4, с. 292-321. 
В тоже время отметим, что одной из проблем в исследовнии деятельности гражданской и военной аАминистрации Смоленска в период осады 1609-1611 гг. явцяется ограниченность сведений о деятемьности земской избы во главе с посадскими старостами (т.н. «Смоленский архив» начала XVII в. долгое время бым доступен только в виде архива воеводской избы). Приступали к решению этой задачи историки Ю.В. Готье, П.А. Медведев и П.В. Епифановский ${ }^{3}$, но не завершившие ее по объективным причинам.

В настоящее время колоссальная работа по разысканию, систематизации и анамизу бумаг Смоленской приказной избы - главного источника по истории обороны города - провели А.А. Селин, Э. Аёфстрем, П. Амбросиани.

Благодаря завершению проекта «Цифровой каталог Стокгольмского Смоленского архива» ${ }^{4}$, мы имеем возможность изучить наиболее полную историю осады Смоленска 1609-1611 гг. Аля полного и всестороннего реконструирования деятельности гражАанской и военной аАминистрации Смоленска в период осады 1609-1611 гг.

Безусловно, в Смоленске действовала традиционная сложившаяся еще в XVI в. система управления: фактически вся полнота вцасти в городе и прилегающих местностях принаАлежала назначаемому Разрядным приказом воеводе, возглавцявшему местный гарнизон, выполнявший судебные функции. Власть воеводы не быма формахьно ничем ограничена.

3 Смутное время Московского государства 1604-1613 г2. Материаль, изданньце Имп. Обществом истории и древностей российских при Московском ун-те, вып. 6: Памятники оборонь Смоленска (1609-1611 г2.), реА. Ю.В. ГОТЬЕ, Москва 1912; П.А. МЕАВЕАЕВ, Смоленская оборона 1609-1611 22. в работах В.П. Мальиева (по материалам архивного фонда), [в:] Исследования памятников письменной культуры в собраниях и архивах отдела рукописей и редких книг: Сб. науч. тр., реА. Н.А. ЕфимовА, АенинграА 1988, с. 31-40; IDEм, Подготовка Смоленской оборонь 1609 г., [в:] Источниковедческое изучение памятников письменной культурь: Сб. науч. тр., под реА. Н.А. ЕФИмовА, Аенинград 1990, с. 72-91; IDEм, К вопросу о регулировании внутренней жизни в осажденном Смоленске в 1609-1611 г2., [в:] Россия от Ивана Грозного до Петра Великого, Санкт-Петербург-Киев 1993, с. 44-56; П.В. ЕПИфАновский, Значение оборонь Смоленска лета - осени 1610 года, „Известия Смоленского Государственного Университета” 2010, № 3; IDEм, Челобитные смолян смоленским воеводам 1609-1610 г2. по вопросам сочиального обеспеченuя, „Известия Смоленского Государственного Университета” 2013, № 3 (23), с. 178-185.

4 Официальная страница Национального архива Швеции. Поиск в Смоленском архиве 1604-1611 гг., https://sok.riksarkivet.se/smolensk?fbclid=IwAR0Pqu20vVxcJv-Sx02Bbh5IM7glsIows5FbzCp1pgYubQ3kblxU5GVy2QU (Аоступ: 20 X 2020). 
Так же он осуществлял сыск беглых крестьян и холопов, сбор налогов и судебных пошлин, обеспечение дворян и служимых Аюдей по прибору землей и денежным жалованием. В крупные города обычно назначались по Ава воеводы. Военная администрация дополнялась должностями городовых приказчиков и стрелецкими головами.

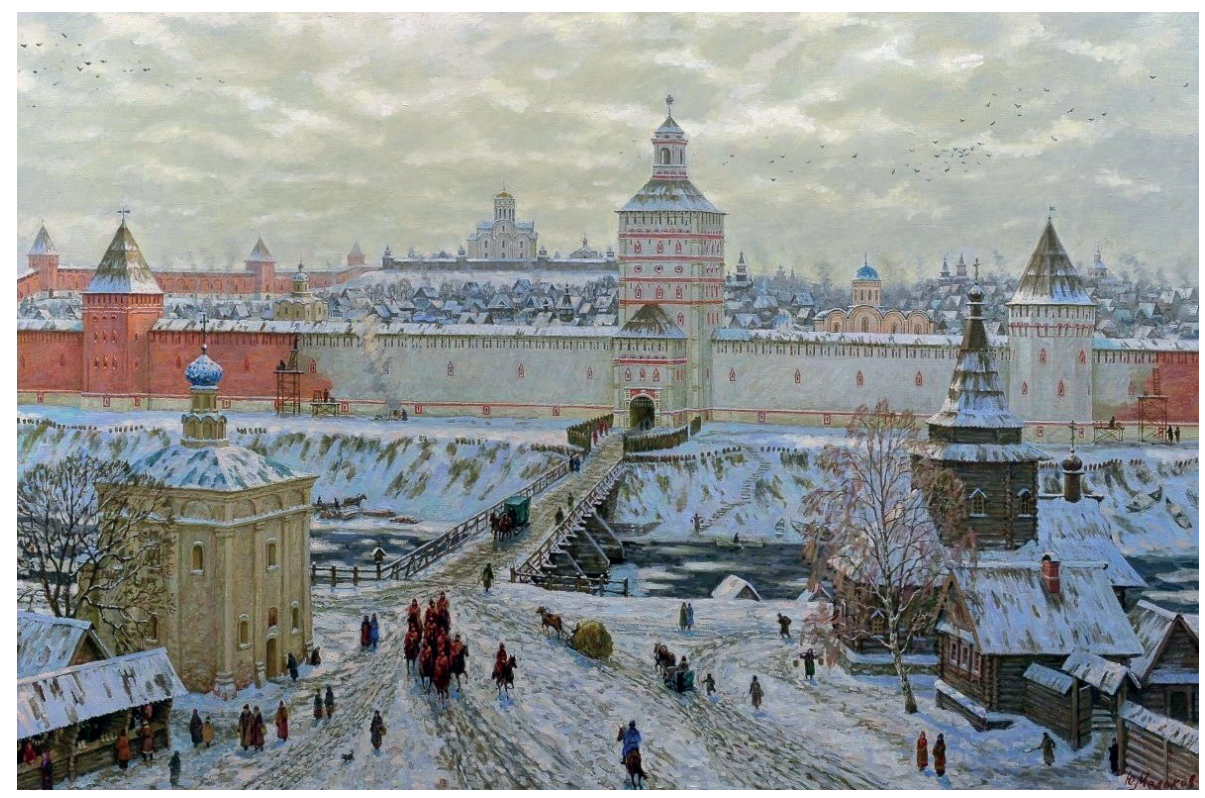

Рис. 2. Смоленск в начале XVII в. В центре - не сохранившаяся Фроловская башня - главные ворота города. На втором плане, на холме - заложенный Владимиром Мономахом первый каменный храм Смоленска. Был частично разрушен в 1611 году в результате подрыва пороховых погребов укрывшимися в соборе уцелевшими защитниками города. На переднем плане фрагмент заднепровского посада, где располагался деревянный острог, сожженный по решению оборонявшихся перед началом осады (Ю.Г. Мельков, Смоленск в начале XVII в., 2015)

Городовые приказчики в XVI-XVII вв. ведали учетом служилых Аворян, строительством и ремонтом городских крепостных укрепцений, боеприпасами, сбором податей, отбыванием натурацьных повинностей и пр. Набирались из числа местных Аворян. В военное время выполняли функции городского военного коменданта (подготовка города к обороне и организация его материального обеспечения, контроль за выполнением караульной скужбы, варка пороха и иные функции осадного головы).

ГАавой Смоленской Аворянской корпорации в период осады бым Воин Фаустович Аивов. Вторым главой Аворянских сотен в Смоленской 
обороне считается Иван Амитриевич Бестужев 5 . Но их Аолжности скорее можно отнести к временным военным должностям с функциями городовых приказчиков. О кратковременной Аолжности острожного гомовы приводится информация ниже.

Стрелецкие головы набирались из числа детей боярских. Согласно известным и доступным данным архива Смоленской воеводской избы за 1608-1611 гг. в числе стрелецких голов упомянуты ФёАор Михайлович Зубов, Васимий Григорьевич Чихачев, Иван Оболешев. Непосредственно в период обороны во главе Смоленских стрельцов стоя Васимий Чихачев. Он же вёц судебные дела между смоленскими стрельцами. После падения Смоленска попац в плен, выжиц как и немногие дворяне, руководившие обороной. На Родину он вернулся только в 1619 г. вместе с Фимаретом, Шеиным и другими русскими пленниками 6 .

Более подробно по организации и деятельности Смоленских служи-

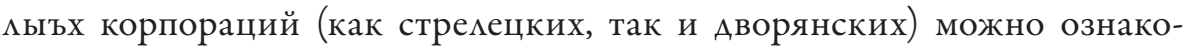
миться в исследованиях А.М. Молочникова ${ }^{7}$, в связи с чем эти вопросы не входят в предмет данного исследования.

Интересы посадского мира представляли выборные земские старосты, сотские и «лучшие люди» из числа горожан ${ }^{8}$. В годы Смуты влияние

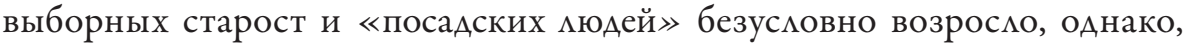
земские старосты и «лучшие $ю$ юи» не получими в годы обороны Смоменска никакой чрезвычайной власти.

Основным органом вцасти в период обороны 1609-1611 гг. в Смоленске осуществцялась традиционно - воеводами и воеводской избой, во главе с городовым дьяком. Именно они издаваци все приказы и распоряжения по организации обороны, формированию воинских подраздемений. От них исходими все решения по организации и регламентации осадной жизни города.

5 А.М. Молочников, Смоленский служильй город..., с. 119, 138, 142.

${ }^{6}$ Ibidem, s. 141; IDEм, Смоленские стрелецкие приказы и их руководители в Смутное время [ЭАектронный ресурс], „История военного дела: исследования и источники” 2012, № 3, c. 321-369.

7 Ibidem, s. 321-369; IDEм, Стрелеикие сотни..., с. 262-272; IDEM, Смоленский служилый гоpoд..., c. 292-321.

8 В.В. Бовыкин, Русскал земля и государство в эпоху Ивана Грозного. Очерки по истории местного самоуправления в XVI веке, Санкт-Петербург 2016, с. 176-177. 
ГАавной задачей городских властей в 1609-1611 гг. являмось укрепление обороноспособности Смоленска и его армии. И эти задачи стали осуществцяться смоленскими воеводами уже до начала обороны города, в 1608 г. Еще в конце 1607 г. в Смоленск прибыли новые воеводы боярин Михаим Борисович Шеин, назначенный первым воеводой, и князь Петр Иванович Горчаков. Во главе воеводской избы тогда стоял дьяк Никон Алексеев (его имя фигурирует в Смоленском делопроизводстве, вплоть Ао падения крепости в 1611 г.) 9 .

Первыми мерами по укрепмению Смоленска можно считать две наказные памяти, данные Шеиным еще в апреле 1608 г. Городовому голове Казимирову было приказано:

ездить в Смоленску и на посаде и в слободах (...) по утру, и в полдень, и вечером и беречи того накрепко, чтоб (...) на посаде, и в слободах воровства и грабежей и всякого дурна, и корчмы, и зерни (...) ни у кого не бымо... изб и мылен цетом не топици, и в ночи никто с огнем не сидец. Вторая грамота была Аана посадским старостам: «и на посаде переписать все Аворы посаАские, чтоб от того Аня, и в городе и на посаде было бережение и воровства никакого не бымо ${ }^{10}$.

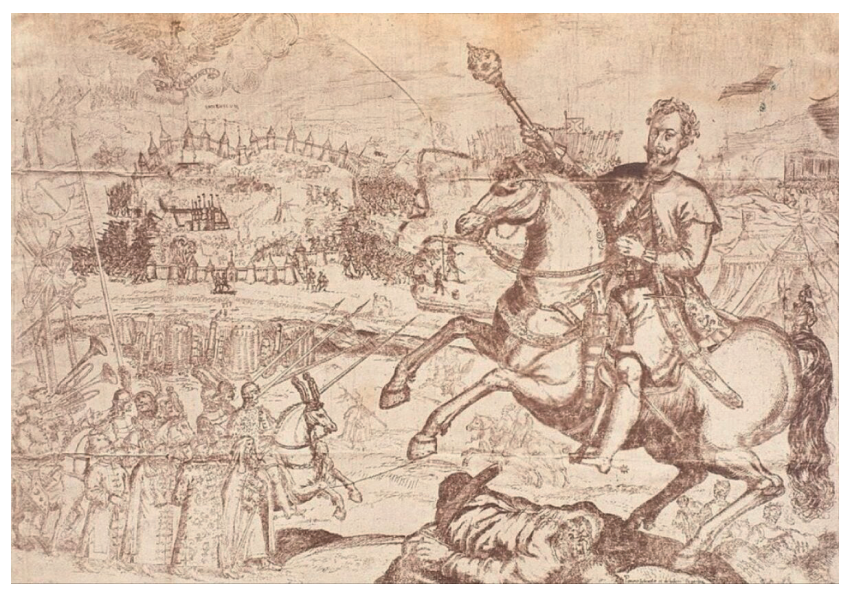

Рис. 3. Портрет Сигизмунда III Вазы на фоне Смоленска (гравюра Томмазо Долабелла (1570-1650), K. BAYER, Wystawa starożytności i zabytków sztuki w Krakowie 1858-1859, Warszawa 1859, tabl. LXX)

\footnotetext{
9 А.М. МолОчников, Смоленский служильий город..., с. 237.
}

${ }_{10}$ Акты исторические, собранные и изданные археографической комиссией, Санкт-Петербург 1841 , т. 2, № 349, с. 416-417. 
Грамоты показывают, что воеводы обцают Аолжной вцастью в городе, что позволяет им приказывать городовым командирам и посаАским старостам осуществлять контроль наА смолянами, и провести первые мероприятия по укреплению обороны города. Так же можно предположить, что воевода обладал необходимыми разведывательными Аанными о возможном походе Сигизмунда III (об этом же указывает C.M. Соловьев ${ }^{11}$ ), о чем свидетельствуют его дацьнейшие Аействия.

С весны 1609 г., в вязи с участившимися набегами польских отрядов на приграничные земли Московского царства, Михаим Шеин организовац строительство застав и засек на подступах к Смоленску. Положение

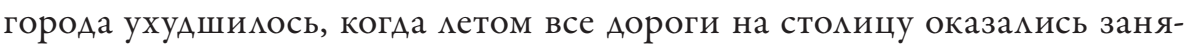

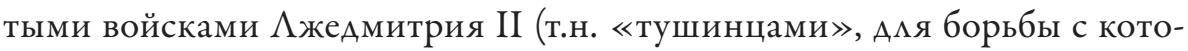
рыми еще с октября 1608 г. воеводы должны быми отправить стрелецкого голову со стремьцами и иных даточных и ратных $\Lambda$ юей ${ }^{12}$, что по понятным причинам ослабимо гарнизон). Воеводская изба в этот период становится штабом Смоленской обороне. В конце августа в воеводской избе быми составцены роспись смоленского гарнизона и роспись артим ерии по башням ${ }^{13}$.

Смоленский гарнизон бым разделен на Аве части. Часть была сформирована в контрштурмовые отряды (примерно 2000 человек)

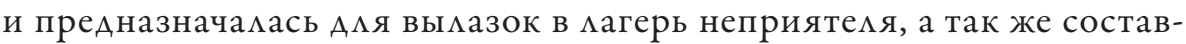

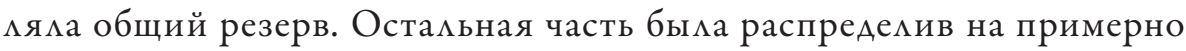
равные по численности 38 отрядов (по количеству башен крепости), каждый из которых охраня отдемьную башню с прилегающим участ-

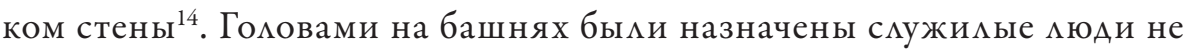
только из Смоленска, но и из Аорогобужа и Вязьмы (результат того, что еще с конца цета 1609 г. воевода М. Шеин активно призывац в состав гарнизона пушкарей, стрельцов и детей боярских из бцизлежащих вотчин).

${ }_{11}$ С.М. Соловьев, История России с древнейших времен, кн. 4, Москва 1960, с. 531.

12 Смутное время Московского..., с. 5.

13 Акты исторические..., т. 2, № 254, 259, с. 301-302, 311-312; Смутное время Московского..., c. 151-158.

${ }_{14}$ А.П. Бутурлин, История Смутного времени в России в начале XVII века, ч. 3, Санкт-Петербург 1846, с. 16. 

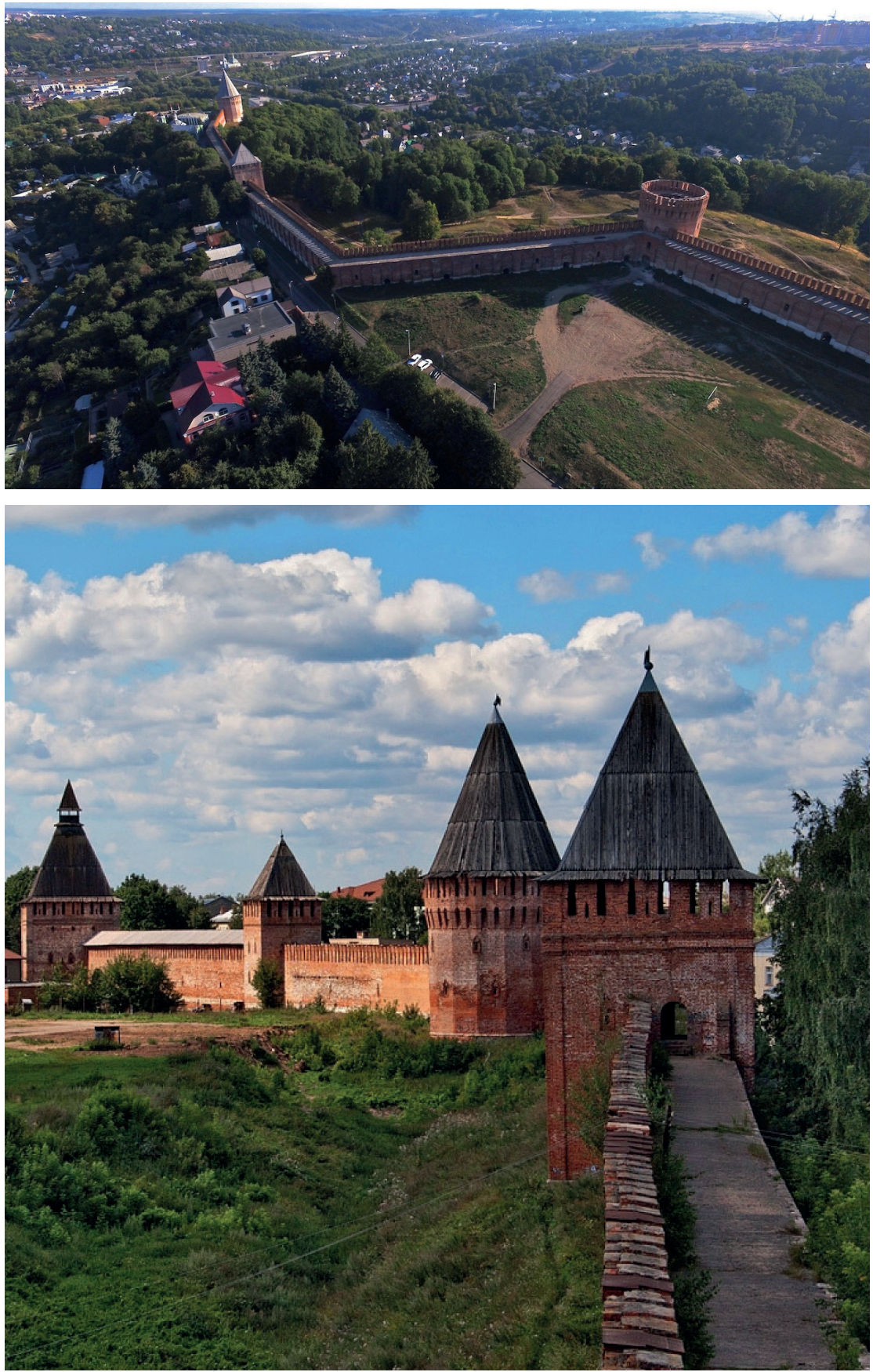

Рис. 4 и 5. Смоленская крепостная стена - фрагмент, современный вид (собрание автора) 
Перед городскими воротами по приказу воеводы были установцены срубы «наподобие избы, так что за сими срубами не бымо прямого прохода, но Аолжно было обходить кругом подие стены, небольшим тесным заулком, которым мог пройти только один человек и провести $\Lambda$ ошаАь ${ }^{15}$.

В направлении главного удара вероятного штурма были предприняты следующие меры. На Аругой стороне $А$ непра бым сооружен укрепленный острог, головой которого бым назначен Григорий Федорович Большой Кокошкин. Но, вслеАствие многочисленности отрядов неприятеАя и во избежание больших жертв среди обороняющихся, было принято решение о сожжении этих деревянных укреплений (которые могли в случае захвата использовать и осаждающие), а имя Г.Ф. Кокошкина как острожного головы больше не упоминается ${ }^{16}$. В предместьях, непосредственно примыкавших к самой каменной крепости (на той же стороне реки, что и город) быми оборудованы деревянные укрепления (они делимись на Крылошевскую (восточную) и Пятницкую (западную) сторону), куда

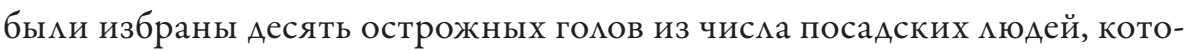
рые должны были объезжать караулы и надзирать за обстановкой.

ВпослеАствии, в связи с уничтожением острога, захватом и разрушением преАместий, перемещением обороны непосреАственно в крепость, надобность в таком мобицьном командном отряде отпаца.

Осенью 1609 г., уже в период осады, Шеин проводит ряд мероприятий, направленных на подчинение городской жизни нуждам обороны, Аля чего воеводе удалось мобимизовать все городские ресурсы. В конце сентября воевода поручим Аворянину Васимию Петрыкину провести осмотр посадских и других дворов применительно к нуждам осады. 22 октября была составлена роспись всего строительного материала в городе. 8 ноября Шеин Аам память посадским старостам, в которой приказывамось провести на посадах меры пожарной безопасности. В ноябре были Ааны 2 памяти о захоронении трупов мошадей ${ }^{17}$ во избежание распространения в осажденном городе эпидемий.

23 ноября 1609 г. Шеин дал память о введении временного судопроизводства. Все судные дема начатые до осады прекращались, а возникшие

\footnotetext{
15 Записки гетмана С. Жолкевского о Московской войне, Санкт-Петербург 1771, с. 29-31.

16 А.М. МолОчников, Смоленский служильй город..., с. 165.

17 Смутное времл Московского..., с. 37, 41, 46, 50.
} 
после 19 сентября 1609 г. должны быми вестись по обычным правимам, и со всеми пошиинами ${ }^{18}$.

В ноябре 1609 г., в связи с начавшимися побегами из крепости, каждый подобный случай разбирался в воеводской избе, и по нему выносимось решение. Тогда же воевода дац две памяти посадским старостам об укреплении Аисцип ины в армии и в отношении уклоняющихся от службы. К Аезертирам предписывацось применять крайнюю меру - смертную казнь ${ }^{19}$.

В декабре 1609 г. в воеводской избе разбирацись Аела о найме на караулы, когда некоторые посадские нанимахи за себя дежурить на стене хомопов. Было арестовано несколько человек, которых подвергли торговой казни: битью кнутом на площаАи ${ }^{20}$.

В апреле 1610 г. Шеин провел еще одно важное мероприятие в городе, которое улучшимо внутреннюю атмосферу среди осажденных. Осенью

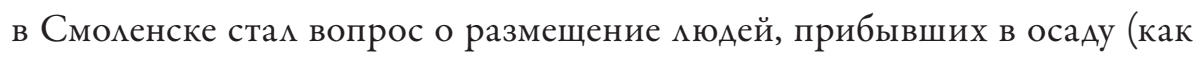
из окрестностей, так и из уничтоженных посадов и острога).

Уже в памяти от 23 ноября 1609 г. воевода особо подчеркивац о необходимости решать вопросы, связанные с «Аворовой теснотой». Зимой эта проблема еще больше обострилась. Цена за квартиру достигла 8 денег и 2 алтына. Поэтому 12 апремя 1610 г. Шеин, после челобитной посаАских мюдей, отменим все наймы до конца осады ${ }^{21}$.

В апреле 1610 г. приказом воеводы в Смоленске вводится должность полицейских надзирателей, которые должны были осуществлять контроль за населением. Город делился на 5 секторов, надзор в которых бы возложен на дворян Курбата Колотяжина, Кузьму Аовотчикова, Ивана Жидовинова, Амитрия Сказина и Ивана Аовотчикова. 21 апреля им бым дан наказ патрулировать город, следить за противопожарным состоянием, бороться с проявцениями пьянства среди насемения ${ }^{22}$. Появление Аанного приказа свидетемьствует о том, что распоряжение воевод о правимах осаАной жизни не всегда выполня ись, и это потребова оо введения Аолжности полицейских наАзирателей с широкими полномочиями.

\footnotetext{
18 Ibidem, s. 47-48.

19 Ibidem.

20 Ibidem, s. 49, 64-65.

21 Ibidem, s. 67-68.

22 Ibidem, s. 77-78.
} 
ЕАинственным изменением в структуре городской гражАанской вцасти периода Смоленской обороны 1609-1611 гг. следует считать возросшую роль земской избы, во главе которой стоями выборные посаАские старосты Аука Горбачев и Юрий Огопьянов (в 1609 и до августа 1610 г.), Оксен Аюкарев и Аанима Аешин (с сентября 1610 г. до падения Смоленска). Земская изба подчинялась воеводам и осуществляма контроль за посадским населением. Основными ее задачами было отправление суда наА посадскими Аюдьми по меАким преступлением, и прежде всего связанных с имуществом, сбор торговых и таможенных пошиин, проведение разАичных имущественных сделок посадских Аюдей.

В исследованиях по военной организации посадского населения Смоленска в период обороны 1609-1611 гг., указано на наличие сформированного командного органа над посадским населением. Отмечается, что при формировании посадского опоччения применялся принцип аАминистративно-территориальный деления города: Пятницкий конец, Полусохи, Сотни, которые в свою очередь делимись на более мелкие отряды во главе с сотниками. Каждая сотня демилась на два пятидесятка по пять десятков в каждом ${ }^{23}$.

Посадское опоцчение вцилось в состав гарнизона крепости и испоцьзовалось как вспомогательные войска, привцекалось к земляным и саперным работам, несению караульной и сторожевой службы, дежурству в «слухах» ${ }^{24}$. Сам гарнизон города, по данным А.Маковского, состав я $\Lambda$ 5400 воинов: крестьян 1500 человек, посаАских 2500 человек (эти Аве

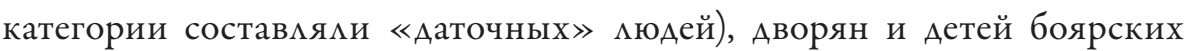
900 человек, стремьцов и пушкарей 500 человек ${ }^{25}$. Учитывая, что основной контингент военного гарнизона Смоленска участвовац в операциях

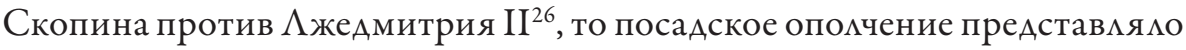
ощутимую помощь в защите крепости.

23 Ibidem, s. 162-164.

24 А.М. Молочников, У Государева дела, у «слухов»: сапернал служба в Смоленске в 16091611 г2. [ЭАектронный ресурс], „История военного дела: исследования и источники” 2014, № 5, с. 23-70; IDEм, Военная политическая организация смоленской городской общины в 1609-1611 22. [Электронный ресурс], „История военного дела: исследования и источники” 2015, Спещиальньй выпуск IV. Смоленские войнь XV-XVII вв., ч. 1, с. 182-203.

25 А. МАКОвСКИЙ, Осада Смоленска, Смоленск 1939.

26 А.М. Молочников, Смоленские стрелецкие приказы и их руководители в Смутное время [Электронный ресурс], „История военного дела: исследования и источники” 2012, № 3, с. 321-369. 
Относительно роли посадской общины в управлении Смоленском Ао сих пор нет еАиного мнения. В.П. Мальцев считает, в сентябре 1609 г. был образован городской совет, состоявший из посадских старост, ставший своеобразным колмективным органом представительской власти, которому подчинялись смоленские воеводы, а воеводская изба совместно с земской избой являлась исполнительным органом при этом «народном правительстве ${ }^{27}$.

Впрочем, эта версия опровергается С.В. Ацександровым: нигде нет сведений о составе этого совета, а в документации воеводской избы есть сведения, что М.Б. Шеин, руководивший обороной Смоленска в 16091611 гг., неоднократно отдавал старостам указания о регламентации осадной жизни в городе $e^{28}$.

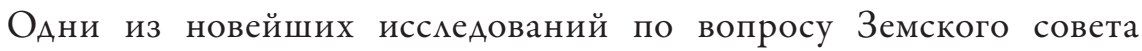
в осажденном Смоленске, отмечают, что Смоленск стац одним из первых городов, в котором ещё в 1609 г. зародикась, а в годы междуцарствия закрепикась система управления думного боярина и воеводы с опорой на земский совет ${ }^{29}$. Еще в посланной смолянами в Москву 9 октября 1609 г. грамоте содержалось заверение преданности и указание об отказе «литовскому королю и радным панам» ${ }^{30}$. Смоляне до ноября 1610 г. сохраняли верность царю Василию Шуйскому. Во время междуцарствия 1610-1611 гг. в условиях отсутствия законного монарха смолянами применяется формула присяги «Московского государства боярам и всей земме» ${ }^{31}$.

Таким образом, можно говорить и о земском союзе всех сословий Смоленской земли, сложившийся в экстреманьных условиях осады 1609-1611 гг. ГАавной причиной возникновения земского союза было то, что и смоленские Аворяне, и посадские Аюди на протяжении всех военных действий начала XVII в. подАерживали центральную власть, и у них не возникало каких-либо причин Аля перехода на сторону самозванцев и польского короля.

27 В.П. МАһьЦЕВ, Борьба за Смоленск, Смоленск 1940, с. 249-254.

28 С.В. АлЕКСАНАРОв, Смоленская осада 1609-1611, Смоленск 2011, с. 171-175.

29 А.М. Молочников, Земский совет в осажденном Смоленске, „Вестник Нижегородского Университета им. Н.И. Аобачевского” 2017, № 2, с. 46-50.

${ }^{30}$ Акты исторические..., т. 2, № 267, с. 319.

31 А.М. Молочников, Земский совет..., с. 46-50. 
Во многом этот союз бым вынужденный, не бым организационно оформлен, полномочия союза не были четко определены, в нем существоваци сословные противоречия, поэтому он не мог быть достаточно прочным. Но эта система управления показала свою надежность в «безгосударское время» и в дацьнейшем использовалась в Первом и во Втором земских ополчениях.

Таким образом, можно сделать вывод, что всю полноту власти в Смоленске в период осады осуществляла воеводская администрация, что вполне закономерно в период военных действий. Именно она издавала все приказы и распоряжения по организации смоленской армии и по регламентации осадной жизни. Воеводам подчинялась земская изба, во главе с посадскими старостами. Но ее роль в период обороны возросла. И это было связано с усилением роли посадской

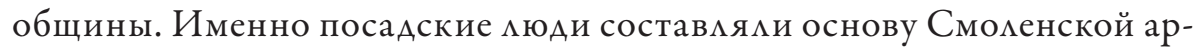
мии, и с ними быми вынуждены считаться воеводы. Так же отметим, что в период осады 1609-1611 гг. в Смоленске сложился всесословный союз, послуживший своеобразным прототипом преАставительных общесословных институтов, а сам город стац прототипом общероссийского сопротивцения.

\section{BIBLIOGRAFIA}

\section{Źródła drukowane}

Акты исторические, собранные и изданные археографической комиссией, т. 2, Санкт-Петербург 1841 (Akty istoricheskiye, sobrannyye i izdannyye arkheograficheskoy komissiyey, t. 2, Sankt-Peterburg 1841).

Записки гетмана С. Жолкевского о Московской войне, Санкт-Петербург 1771 (Zapiski getmana S. Zholkevskogo o Moskovskoy voyne, Sankt-Peterburg 1771).

Смутное время Московского государства 1604-1613 г2.: Материальь, изданные Имп. Обществом истории и древностей российских при Московском ун-те, выл. 6: Памятники обороны Смоленска (1609-1611 г2.), под реА. Ю.В. Готье, Москва 1912 (Smutnoye vremya Moskovskogogosudarstva 1604-1613 gg.: Materialy, izdannyye Imp. Obshchestvom istorii i drevnostey rossiyskikh Primoskovskom un-te, vyl. 6: Pamyatniki oborony Smolenska (1609-1611 gg.), red. Yu. V. Got'ye, Moskva 1912). 


\section{Opracowania}

Александров С., Смоленская осада 1609-1611 г2., Смоленск 2011 (Aleksandrov S., Smolenskaya osada 1609-1611 gg., Smolensk 2011).

Бовыкин В.В., Руская земля игосударство в эпоху Ивана Грозного. Очерки по истории местного самоуправления в XVI веке, Санкт-Петербург 2016 (Bovykin V.V., Russkaya zemlya i gosudarstvo v epokhu Ivana Groznogo. Ocherki po istorii mestnogo samoupravleniya $v$ XVI veke, Sankt-Peterburg 2016).

Бутурлин А.П., История Смутного времени в России в начале XVII века, ч. 3, Санкт-Петербург 1846 (Buturlin D.P., Istoriya Smutnogo vremeni v Rossii v nachale XVII veka, ch. 3, Sankt-Peterburg 1846).

Епифановский П.В., Значение оборонь Смоленска лета-осени 1610 года, „Известия Смоленского Государственного Университета" 2010, № 3, с. 220-225 (Yepifanovskiy P.V., Znacheniye oborony Smolenska leta-oseni 1610 goda, „Izvestiya Smolenskogo Gosudarstvennogo Universiteta” 2010, № 3, s. 220-225).

Епифановский П.В., Челобитные смолян смоленским воеводам 1609-1610 г2. по вопросам сочиального обеспечения, „Известия Смоленского Государственного Университета” 2013, № 3 (23), c. 178-185 (Yepifanovskiy P.V., Chelobitnyye smolyan smolenskim voyevodam 1609-1610 gg. po voprosam sotsialnogo obespecheniya, „Izvestiya Smolenskogo Gosudarstvennogo Universiteta” 2013, № 3 (23), s. 178-185).

Маковский А., Осада Смоленска, Смоленск 1939 (Makovskiy D., Osadas Smolenska, Smolensk 1939).

Мамьцев В.П., Борьба за Смоленск, Смоленск 1940 (Maltsev V.P., Borba za Smolensk, Smolensk 1940).

Медведев П.А., Квопросу орегулировании внутреннейжизни в осажденном Смоленске в 1609-1611 г2., [в:] Россия от Ивана Грозного до Петра Великого, Санкт-Петербург-Киев 1993, с. 44-56 (Medvedev P.A., K voprosu o regulirovanii vnutrenney zhizni vosazhdennom Smolenske v 1609-1611 gg., [v:] Rossiya Otivana Groznogo do Petra Velikogo, Sankt-Peterburg-Kiyev 1993, s. 44-56).

Медведев П.А., Подготовка Смоленской обороны 1609 г., [в:] Источниковедческое изучение памятников письменной культуры, ред. Н.А. Ефимов, АенинграА 1990 , c. 72-91 (Medvedev P.A., Podgotovka Smolenskoy oborony 1609 g., [v:] Istochnikovedcheskoye izucheniye pamyatnikov pismennoy kultury, red. N.A. Yefimov, Leningrad 1990, s. 72-91).

Медведев П.А., Смоленскал оборона 1609-1611 г2. в работах В.П. Мальцева (по материалам архивного фонда), [в:] Исследования памятников писвменной культурыв вобранияхи архивахотделарукописейиредкихкниг, реА. Н.А. Ефимов,

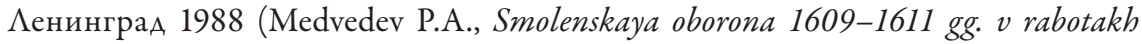
V.P. Mal'tseva (po materialam arkhivnogo fonda), [v:] Issledovaniyapamyatnikovpismennoy kultury $v$ sobraniyakh i arkhivakh otdela rukopisey i redkikh knig, red. N.A. Yefimov, Leningrad 1988). 
Молочников А.М., Смоленский служильй город в Смутное время, Аиссертация ... кандидата исторических наук: 07.00.02 (Молочников Александр Михайлович), место защиты: Санкт-Петербургский институт истории РАН, Санкт-Петербург 2014, c. 237 (Molochnikov A.M., Smolenskiy sluzhilyy gorod v Smutnoye vremya, dissertatsiya ...kandidata istoricheskikh nauk: 07.00.02 (Molochnikov Aleksandr Mikhaylovich), mesto zashchity: Sankt-Peterburgskiy institut istorii PAN, Sankt-Peterburg 2014, s. 237).

Молочников А.М., Военная политическая организация смоленской городской общины в 1609-1611 г2. [Электронный ресурс], „История военного дела: исследования и источники" 2015, Специальный выпуск IV: Смоленские войны XV-XVII вв., ч. 1, c. 182-203 (Molochnikov A.M., Voyennaya politicheskaya organizatsiya smolenskoy gorodskoy obshchiny $v 1609-1611 \mathrm{gg}$. [Elektronnyy resurs], „Istoriyavoyennogo dela: issledovaniya i istochniki” 2015, Spetsial'nyy vypusk IV: Smolenskiye voyny $X V$ XVII vv., ch. 1, s. 182-203).

Молочников А.М., Земский совет в осажденном Смоленске, „Вестник Нижегородского Университета им. Н.И. Аобачевского” 2017, № 2, с. 46-50 (Molochnikov A.M., Zemskiy sovet v osazhdennom Smolenske, „Vestnik Nizhegorodskogo Universiteta im. N.I. Lobachevskogo” 2017, № 2, s. 46-50).

Молочников А.М., Смоленские стрелецкие приказы и их руководители в Смутное время [Электронный ресурс], „История военного дела: исследования и источники" 2012, № 3, с. 321-369 (Molochnikov A.M., Smolenskiye streletskiye prikazy i ikhrukovoditeli v Smutnoye vremya [Elektronnyy resurs], „Istoriya voyennogo dela: issledovaniya i istochniki” 2012, №3, s. 321-369).

Молочников А.М., Смоленский служильй город Смутного времени. Часть I. Поместное верстание 7114 (1605/06) года [Эмектронный ресурс], „История военного дела: исследования и источники" 2013, № 4, с. 292-321 (Molochnikov A.M., Smolenskiy sluzhilyy gorod Smutnogo vremeni. Chast'I. Pomestnoye verstaniye 7114 (1605/06) goda [Elektronnyy resurs], „Istoriya voyennogo dela: issledovaniya i istochniki” 2013, № 4, s. 292-321).

Молочников А.М., Стрелещкие сотни в Смоленской обороне 1609-1611 22. К проблеме статистического анализа, [в:] Четвертая Международная научно-практическая конференщия «Война и оружие. Новые исследования и материаль» 15-17 мал 2013 2., Санкт-Петербург 2013, с. 262-272 (Molochnikov A.M., Streletskiye sotni $v$ smolenskoy oborone $1609-1611 \mathrm{gg}$. K probleme statisticheskogo analiza, [v:] Chetvertaya Mezhdunarodnaya nauchno-prakticheskaya konferentsiya «Voyna i oruzhiye. Novyye issledovaniya i materialy» 15-17 maya 2013 g., Sankt-Peterburg 2013, s. 262-272).

Молочников А.М., У Государева дела, у «слухов»: сапернал служба в Смоленске в 1609-1611 22. [Электронный ресурс], „История военного дела: исследования и источники” 2014, № 5, с. 23-70 (Molochnikov A.M., U Gosudareva dela, u «slukhov»: sapernaya sluzhba $v$ Smolenske v 1609-1611 gg. [Elektronnyy resurs], „Istoriyavoyennogo dela: issledovaniya i istochniki” 2014, № 5, s. 23-70). 
Прохоров В., Заметки о топографии Смоленска (1-я половина XVII века): Большие сотни Смоленска - административные и исторические части города. Население Смоленска и пригородов, „Край Смоленский” 2017, № 3, s. 19-34 (Prokhorov V., Zametki otopografii Smolenska (1-ya polovina XVII veka): Bol'shiye sotni Smolenska - administrativnyye i istoricheskiye chasti goroda. Naseleniye Smolenska iprigorodov, „Kray Smolenskiy” 2017, № 3, s. 19-34).

Радков Н., Смоленск в Смутное время, [в:] Смоленская старина, ч. 2, Смоленск 1914 (Radkov N., Smolensk v Smutnoye vremya, [v:] Smolenskaya starina, ch. 2, Smolensk 1914).

Смоленскал оборона, Смоленск 1939 (Smolenskaya oborona, Smolensk 1939).

Селин А.А., Женшины в осаждённом Смоленске, [в:] Аа веселится Новъградъ. Ма Novgorod fröjda sig. Hyllningsskrift till Elisabeth Löfstrand, Utg. P. Ambrosiani, P. Bodin, N. Zorikhina Nilsson, Stockholm 2016 (Selin A.A., Zhenshchinyv osazhdënnom Smolenske, [v:] Da veselit.sya Novgrad. Må Novgorod fröjda sig. Hyllningsskrift till Elisabeth Löfstrand, Utg. P. Ambrosiani, P. Bodin, N. Zorikhina Nilsson, Stockholm 2016).

Селин А.А., Королевские пожалования под Смоленском: случай Ржевских, „Аревняя Русь. Вопросы медиевистики” 2017, № 3 (69), с. 122-123 (Selin A.A., Korolevskiye pozhalovaniya pod Smolenskom: sluchay Rzhevskikh, „Drevnyaya Rus. Voprosy mediyevistiki” 2017, № 3 (69), s. 122-123).

Соловьев С.М., История России с древнейших времен, кн. 4, Москва 1960 (Solovyev S.M., Istoriyarossii s drevneyshikh vremen, kn. 4, Moskva 1960).

Тюменцев И.О., Польский коронньий гетман Станислав Жолкевский и Ян Сапега летом-осенью 1610 2. (по материалам личной переписки), И.О. Тюменцев, Н.А. Тупикова, Н.Е. Тюменцева, С.В. Мирский, „Вестник Волгоградского Государственного Университета. Серия 4, История. Регионоведение. Международные отношения" 2005, вып. 10, с. 108-125 (Tyumentsev I.O., Pol'skiy koronnyy getman Stanislav Zholkevskiy i Yan Sapega letom-osen'yu $1610 \mathrm{~g}$. (po materialam lichnoy perepiski), I.O. Tyumentsev, N.A. Tupikova, N.Ye. Tyumentseva, S.V. Mirskiy, „Vestnik Volgogradskogo Gosudarstvennogo Universiteta. Seriya 4, Istoriya. Regionovedeniye. Mezhdunarodnyye otnosheniya” 2005, vyp. 10, s. $108-125)$.

\section{Netografia}

Официальная страница Национацьного архива Швеции. Поиск в Смоленском архиве 1604-1611 гг., https://sok.riksarkivet.se/smolensk?fbclid=IwAR0Pqu20 vVxcJv-Sx02Bbh5IM7glsIows5FbzCp1pgYubQ3kblxU5GVy2QU (Аоступ: $20 \mathrm{X}$ 2020). 


\author{
Konstantin Kupchenko (Константин Купченко) \\ Natalya Nikitina (Наталья Никитина)
}

\title{
ADMINISTRATION OF SMOLENSK DURING THE SIEGE IN YEARS 1609-1611
}

Summary. The present article deals with poorly researched questions of the functioning of the administrative bodies of Smolensk during the defence period 1609-1611. The work on the basis of current sources and contemporary historiography deals with the management of the Smolensk period. The relevance of the project stems from the very limited knowledge of day-to-day management issues, which have not been reflected in both ad hoc and comprehensive studies of the history of the region during the Dark Time period. The work is based on strict adherence to the principle of historism. The article uses the most scientific and productive methodological guidelines of modern historical research directions. The integrated approach of the study involves the following methods: historical description, historical analysis, comparative, micro-history. The whole complex of archival heuristics tools is used in working with the documentary material. The authors investigate whether there were any changes in the structure of city administration at that time and which authorities in the defense period exercised authority over the population of Smolensk. The powers, competence and practical activities of the voivodeship administration and the civil administration (Zemstvo, Posad) have been examined. The authors conclude that the entire authority in the city was in the hands of the voivodes. It was from them that all orders and orders on organization of the Smolensk army, strengthening of defense capability and regulation of siege life were issued. But at the same time, it is noted that during the siege of 1609-1611. In Smolensk, a peculiar corporation of military and civilian administrative authorities has been formed to coordinate common efforts for the defence of the city.

Keywords: Smolensk, Time of the Dark, Voivodeship House, Earthen House, Defense, Posad People, Militia 